\title{
EDITORIAL
}

\section{EL MECIP y la Facultad de Ciencias Médicas - Universidad Nacional de Asunción}

\author{
Machain Vega, Gustavo
}

Universidad Nacional de Asunción, Facultad de Ciencias Médicas, MECIP. San Lorenzo, Paraguay.

El Modelo Estándar de Control Interno del Paraguay - MECIP - es la propuesta a toda institución pública del país de una estructura de Control Interno para la organización y principios, fundamentos, conceptos básicos de sustento y también herramienta de apoyo a la propia gestión. Un sistema de control interno Institucional comprende los planes, métodos, políticas y procedimientos utilizados para cumplir con la Misión, la Visión, el Plan Estratégico y los objetivos Institucionales $(1,2)$.

La Facultad de Ciencias Médicas - FCM - de la Universidad Nacional de Asunción UNA - en su gran intención comprometida de lograr una función administrativa integra, eficaz y transparente ha realizado avances en sus indicadores del MECIP en dicho proceso (3-5). El puntaje MECIP de 1,58 a finales del 2015 (6) y su avance sostenido en las últimas evaluaciones: 2,78 y 3.33 de puntaje en los semestres de $2.016(7,8)$; 3,52 y 3,61 en los semestres de $2017(9,10)$ y la puntuaciones de 3,72 y 3,74 en los semestres de $2018(11,12)$; nos orientan hacia los pasos realizados en nuestra Institución de Educación Superior y de nuestro Hospital Universitario "Hospital de Clínicas" en dicho proceso.

Lo importante a resaltar es que el avance es progresivo pero sostenido y aún con muchos desafíos institucionales por lograr. La evaluación de la estrategia, la gestión y los mecanismos de evaluación de la institución a fin de garantizar el desarrollo de sus funciones bajo principios de responsabilidad, eficiencia, eficacia, calidad y trasparencia y la contribución al cumplimiento de los objetivos institucionales, en concordancia con los fines sociales del estado paraguayo son parte de este proceso.

Finalmente quisiera agradecer a todos los componentes - Docentes, egresados, estudiantes y funcionarios - de la gran familia de la Facultad de Ciencias Médicas - Universidad Nacional de Asunción por su gran compromiso con nuestra Institución y a seguir avanzando todos.

$$
\begin{gathered}
\text { Prof. Dr. Gustavo Machain Vega } \\
\text { Vice Decano FCM UNA } \\
\text { Profesor Titular FCM UNA } \\
\text { Coordinador MECIP FCM UNA }
\end{gathered}
$$

\section{REFERENCIAS BIBLIOGRAFICAS}

1. Resolución Nro $424 / 2008$ de la Contraloría General de la Republica. Se aprueba el Modelo Estándar de Control Interno para las Entidades Públicas del Paraguay - MECIP y se dispone su Adopción al Interior de la Contraloría General de la República.

2. Resolución Nro 377/2016 de la Contraloría General de la República. Se adopta la Norma de requisitos mínimos para un Sistema de Control Interno del Modelo Estándar de Control Interno para Instituciones Públicas del Paraguay - MECIP 2015.

3. Acta de Compromiso para la Implementación del MECIP, del 17 de marzo del 2016. De la Facultad de Ciencias Médicas. UNA

Autor correspondiente: Prof. Dr. Gustavo Machain Vega. Vice Decano, Facultad de Ciencias Médicas, Universidad Nacional de Asunción. San Lorenzo, Paraguay. E-mail:gmmachain@yahoo.com.

Fecha de recepción el 25 de Marzo del 2019; aceptado el 29 de Marzo del 2019. 
4. Resolución D. Nro 20/2016 de la Facultad de Ciencias Médicas - UNA. Se aprueba la integración del cómitre de Control Interno de la Facultad de Ciencias Médicas de la Universidad Nacional de Asunción.

5. Resolución D. Nro 236/2016 de la Facultad de Ciencias Médicas - UNA. Se ratifica la adopción e implementación del Modelo Estándar de Control Interno para Instituciones Públicas del Paraguay (MECIP) en la Facultad de Ciencias Médicas de la Universidad Nacional de Asunción y se designan Responsable-Coordinador General

6. Informe del Formulario de Medición de Grado de Avance del MECIP Versión 3. Año 2015 Segundo Semestre
7. Informe del Formulario de Medición de Grado de Avance del MECIP Versión 3. Año 2016 Primer Semestre

8. Informe del Formulario de Medición de Grado de Avance del MECIP Versión 3. Año 2016 Segundo Semestre

9. Informe del Formulario de Medición de Grado de Avance del MECIP Versión 3. Año 2017 Primer Semestre

10. Informe del Formulario de Medición de Grado de Avance del MECIP Versión 3. Año 2017 Segundo Semestre

11. Informe del Formulario de Medición de Grado de Avance del MECIP Versión 3. Año 2018 Primer Semestre

12. Informe del Formulario de Medición de Grado de Avance del MECIP Versión 3. Año 2018 Segundo Semestre. 


\title{
EDITORIAL
}

\section{MECIP and the Faculty of Medical Sciences of the National University of Asunción}

\author{
Machain Vega, Gustavo
}

Universidad Nacional de Asunción, Facultad de Ciencias Médicas, MECIP. San Lorenzo, Paraguay.

The Standard Model of Internal Control of Paraguay, in other words MECIP, is a program that establishes the monitoring and evaluation of all the internal systems from the governmental agencies. Basically, an institutional internal control system encompasses the plans, methods, policies, and procedures employ to act in accordance with the mission, vision, strategic plan as well as the institutional objectives $(1,2)$.

The Faculty of Medical Sciences of the National University of Asunción has made progress in the MECIP's indicators in order to achieve an integrated, effective, and transparent public service (3-5). Indeed, the MECIP score of 1,58 at the end of 2015 (6) and its sustained progress in last evaluations: 2,78 and 3,33 of points in semesters of $2.016(7,8) ; 3,52$ and 3,61 in semesters of $2017(9,10)$, and points of 3,72 and 3,74 in semesters of $2018(11,12)$ respectively, clearly lead us towards the steps taken at the Hospital of Clinicas - our University Hospital- in the above - mentioned program.

Despite the progressive and sustained advance, there are still many institutional challenges to be achieved, naturally. In truth, part of this whole process also includes both an evaluation of the strategy and management as well as an assessment of institutional mechanisms. In this respect, the goal is to guarantee more accountable, effective and efficient public services under values of high quality and transparency that fulfill completely the institutional objectives, in accordance with the Paraguay as a Social state.
Finally, I would like to thank all the members of the great family of the Faculty of Medical Sciences of the National University of Asuncion: professors, graduate students, undergraduate students, and public servants for their great commitment to our institution. Undoubtedly, we must continue forward.

$$
\begin{gathered}
\text { Prof. Dr. Gustavo Machain Vega } \\
\text { Vice Decano FCM UNA } \\
\text { Profesor Titular FCM UNA } \\
\text { Coordinador MECIP FCM UNA }
\end{gathered}
$$

\section{BIBLIOGRAPHIC REFERENCES}

1. Resolución Nro $424 / 2008$ de la Contraloría General de la Republica. Se aprueba el Modelo Estándar de Control Interno para las Entidades Públicas del Paraguay - MECIP y se dispone su Adopción al Interior de la Contraloría General de la República.

2. Resolución Nro 377/2016 de la Contraloría General de la República. Se adopta la Norma de requisitos mínimos para un Sistema de Control Interno del Modelo Estándar de Control Interno para Instituciones Públicas del Paraguay - MECIP 2015.

3. Acta de Compromiso para la Implementación del MECIP, del 17 de marzo del 2016. De la Facultad de Ciencias Médicas. UNA

4. Resolución D. Nro 20/2016 de la Facultad de Ciencias Médicas - UNA. Se aprueba la integración del cómitre de Control Interno de la Facultad de Ciencias Médicas de la Universidad Nacional de Asunción.

5. Resolución D. Nro 236/2016 de la Facultad de Ciencias Médicas - UNA. Se ratifica la adopción e implementación del Modelo Estándar de Control Interno para Instituciones Públicas del Paraguay (MECIP) en la Facultad de Ciencias Médicas de la Universidad Nacional de Asunción y se designan Responsable-Coordinador General

Autor correspondiente: Prof. Dr. Gustavo Machain Vega. Vice Decano, Facultad de Ciencias Médicas, Universidad Nacional de Asunción. San Lorenzo, Paraguay. E-mail:gmmachain@yahoo.com.

Fecha de recepción el 25 de Marzo del 2019; aceptado el 29 de Marzo del 2019. 
6. Informe del Formulario de Medición de Grado de Avance del MECIP Versión 3. Año 2015 Segundo Semestre

7. Informe del Formulario de Medición de Grado de Avance del MECIP Versión 3. Año 2016 Primer Semestre

8. Informe del Formulario de Medición de Grado de Avance del MECIP Versión 3. Año 2016 Segundo Semestre

9. Informe del Formulario de Medición de Grado de Avance del MECIP Versión 3. Año 2017 Primer Semestre
10. Informe del Formulario de Medición de Grado de Avance del MECIP Versión 3. Año 2017 Segundo Semestre

11. Informe del Formulario de Medición de Grado de Avance del MECIP Versión 3. Año 2018 Primer Semestre

12. Informe del Formulario de Medición de Grado de Avance del MECIP Versión 3. Año 2018 Segundo Semestre 